\title{
PKM: KELOMPOK USAHA KERIPIK PISANG "CINTA" DAN "ROMANTIS" MANURUN KHAS BANJAR DI BANJARBARU DAN MARTAPURA
}

\author{
Thresye $^{1^{*}}$, Nurul Huda ${ }^{2}$ \\ ${ }^{1 *}$ Program Studi Matematika, Universitas Lambung Mangkurat \\ ${ }^{2}$ Program Studi Matematika, Universitas Lambung Mangkurat \\ Corresponding author : \\ E-mail : thresyetiti.unlam@gmail.com
}

Diterima 30 April 2018, Disetujui 5 Mei 2018

\begin{abstract}
ABSTRAK
Desa Pesayangan , Kec. Martapura, Kab. Banjar merupakan salah satu penghasil buah pisang. Di Desa Pesayangan terdapat beberapa UKM keripik Pisang sebagai usaha utama masyarakat. Selain di Martapura terdapat pula UKM keripik Pisang yang berada di desa Guntung Manggis Kecamatan Landasan Ulin Kota Banjarbaru. Dua UKM diataranya yang menjadi mitra kegiatan PKM adalah UKM Mawar penghasil keripik Pisang "CINTA" di Guntung Manggis Banjarbaru dan UKM Kenanga penghasil keripik Pisang "ROMANTIS" di Pesayangan Martapura.Berdasarkan keterangan yang dihimpun dari dua kelompok UKM keripik pisang terdapat beberapa masalah dan kendala dalam menjalankan usaha keripik pisang. Kendala dan masalah tersebut adalah proses produksi, belum adanya diversifikasi rasa, belum adanya ijin usaha atau PIRT dan menejemen usaha. Pembuatan atau produksi keripik pisang masih menggunakan peralatan tradisional dan dilakukan secara manual, sehingga produksi tidak optimal dan berakibat tidak dapat memenuhi permintaan pasar, belum adanya diversifikasi rasa, dan belum adanya nomor ijin usaha atau PIRT, selain itu menejemen usaha yang masih konvensional, yaitu mencampurkan antara keuangan rumah tangga dan keuangan UKM, menyebabkan tidak diketahuinya untung rugi dari usaha keripik pisang tersebut. Hal ini menjadikan usaha keripik pisang di Guntung Manggis dan Pesayangan belum berkembang. Hal ini juga yang menyebabkan daya saing keripik pisang produksi UKM Mawar desa Guntung Manggis dan UKM Kenanga desa Pesayangan belum bisa bersaing dengan produk dari Jawa yang dikemas sangat bagus dan serta variasi rasa yang menarik. Hasil Luaran yang dicapai dari program PKM ini khususnya untuk pihak mitra adalah: terdapat peralatan produksi keripik pisang, peningkatan produksi keripik pisang hingga $50 \%$ dari 4 tandon per minggu menjadi 6 tandon perminggu, meningkatkan pendapatan UKM keripik pisang hingga $45 \%$ dari 1,5 Juta perbulan menjadi 2 Juta perbulan, terdapat variasi rasa keripik, terdapat ijin usaha atau PIRT (Proses), terdapat kemasan yang menarik untuk mengemas keripik pisang dan terdapat jalinan kerja sama dengan minimarket dan toko oleh-oleh untuk memperluas jaringan pemasaran.
\end{abstract}

Kata kunci: UKM Keripik Pisang, Teknologi Tepat Guna, Manajemen Usaha, PIRT, Jaringan Pemasaran.

\section{ABSTRACT}

Pesayangan village, Sub-distric Martapura, Distric Banjar is one of the producers of bananas. In Pesayangan village there are some UKM Banana chips as the main business of society. In addition to Martapura there are also UKM Banana chips located in the village Guntung Manggis Subdistrict Ulin City Banjarbaru. Two UKM who are partners of PKM activities are UKM Banana producers of "CINTA" Banana flour in Guntung Manggis Banjarbaru and UKM Kenanga producer of "ROMANTIS" Banana Chips in Pesayangan Martapura. Based on information gathered from two groups of banana chips, there are some problems and obstacles in running a banana chip business. Constraints and problems are the production process, the lack of diversification of flavors, the absence of a business license or PIRT and business management. The production or production of banana chips still using traditional equipment and done manually, so that the production is not optimal and can not meet the market demand, the lack of diversification of taste, and the absence of business license number or PIRT, in addition to the conventional business management, between household finance and UKM finance, causing no loss of knowledge about the banana chips business. This makes the business of banana chips in Guntung Manggis and Pesayangan not yet developed. This also causes the competitiveness of banana chips production of UKM Mawar village Guntung Manggis and UKM Kenanga Pesayangan village can not compete with products from Java that is packaged very well and interesting variations of flavors. Output achieved from PKM program is especially for the partner are: there are banana chip 
production equipment, banana chips production increase up to $50 \%$ from 4 tandon per week to 6 tank per week, increasing UKM chips banana income up to 45\% from 1.5 Million per month to 2 Million per month, there are variations of flavor chips, there are business license or PIRT (Process), there is an attractive packaging for packing banana chips and there is cooperation with minimarket and gift shop to expand the marketing network.

Keywords: UKM Banana Chips, Appropriate Technology, Business Management, PIRT, Marketing Network.

\section{PENDAHULUAN}

Pisang merupakan buah yang terus berbuah. Berbagai macam jenis pisang yang tumbuh di Kalimantan, namun yang khas adalah pisang manurun. Berdasarkan keterangan yang dihimpun dari kelompok UKM keripik pisang terdapat beberapa masalah dan kendala dalam proses produksi dan menejemen usaha. Kendala tersebut adalah peralatan yang digunakan masih tradisional dan dilakukan secara manual, sehingga produksi tidak optimal dan berakibat tidak dapat memenuhi permintaan pasar. Rasa keripik produksi UKM mitra juga masih satu jenis saja yaitu original, diversifikasi rasa keripik belum dilakukan karena belum ada peralatan untuk mencampur keripik dengan bumbu aneka rasa. Selain itu menejemen usaha yang masih konvensional, dan belum adanya ijin usaha atau belum memiliki PIRT, menjadikan usaha keripik pisang di Guntung Manggis dan Pesayangan belum berkembang. Hal ini juga yang menyebabkan daya saing keripik pisang produksi UKM desa Guntung Manggis dan Pesayangan belum bisa bersaing dengan produk dari Jawa yang dikemas sangat menarik.

Berdasarkan uraian di atas, permasalahan dan kendala UKM keripik pisang perlu ditangani secara komprehensif, agar tidak menjadi kendala dalam perkembangan usaha keripik pisang ke depannya. Oleh karena itu, diperlukan suatu usaha untuk mengatasi permasalahan pada UKM keripik pisang, dalam rangka memberikan percepatan dan akselarasi usaha keripik pisang yang lebih maju dan lebih menguntungkan.

\section{Permasalahan Mitra}

Berdasarkan observasi baik melalui pengamatan langsung maupun diskusi dengan UKM Mawar dan UKM Kenanga maka di rumuskan beberapa permasalahan, yaitu:

1. Bagaimana cara meningkatkan produksi keripik pisang sehingga dapat memenuhi permintaan pasar?

2. Bagaimana menciptakan diversifikasi rasa keripik pisang ?

3. Bagaimana membuat disain dan kemasan keripik pisang yang menarik ?

4. Bagaimana melakukan manajemen usaha yang benar?
5. Bagaimana menjalin kerja sama dengan minimarket dan toko oleh-oleh untuk memperluas jaringan pemasaran?

Kelompok usaha keripik pisang (UKM) dan pemerintah setempat sangat mengharapkan dan mendukung kerjasama dengan pihak luar terutama kalangan Perguruan Tinggi untuk menerapkan teknologi tepat guna yang telah teruji untuk mengatasi permasalahan produksi keripik pisang, untuk meningkatkan kesejahteraan masyarakat. Harapan dan dukungan ini beralasan sekali karena pemberdayaan masyarakat ini selaras dengan program pemerintah kota Banjarbaru dan Kabupaten Banjar yaitu memaksimalkan potensi sumber daya alam untuk mensejahterakan rakyat.

\section{Teknologi Tepat Guna}

Sektor usaha kecil dan menengah (UKM) memiliki kontribusi yang cukup penting dalam pembangunan nasional. Hal ini disebabkan karena UKM mampu mengurangi pengangguran, memerangi kemiskinan serta mampu bertahan dimasa krisis ekonomi. Pisang mengandung kalori (146 kal), air (62,5 g), protein $(1,2 \mathrm{~g})$, lemak $(0,3 \mathrm{~g})$, karbohidrat $(34 \mathrm{~g})$, kalsium (33 $\mathrm{mg}$ ), vitamin C (30 mg). Selain itu, di dalam pisang terdapat juga nutrisi-nutrisi besi, fosfor, dan vitamin B 1 (Rukmana, 2000). Pisang juga mengandung empat kelompok nutrisi, yaitu karbohidrat, lemak,protein dan mineral. Keunggulan pisang terutama pada karbohidrat dan lemak yang merupakan sumber utama bahan bakar pembangkit energi tubuh.

Desa Pesayangan, Kec. Martapura, Kab. Banjar merupakan sentra penghasil pisang dengan rata-rata produksi perhektar mencapai 144,06 $\mathrm{Kw} / \mathrm{Ha}$ (Dinas Pertanian, Perkebunan dan Peternakan Kab. Banjar, 2013). Di Desa Pesayangan terdapat beberapa UKM keripik Pisang sebagai usaha utama masyarakat. Selain di Martapura terdapat pula UKM keripik Pisang yang berada di desa Guntung Manggis Kecamatan Landasan Ulin Kota Banjarbaru. Dua UKM diataranya yang menjadi mitra kegiatan PKM adalah UKM Mawar penghasil keripik Pisang "CINTA" di Guntung Manggis Banjarbaru dan UKM Kenanga penghasil keripik Pisang "ROMANTIS" di Pesayangan Martapura. Sebagai usaha utama, kelompok UKM keripik pisang di desa Guntung 
Manggis dan Pesayangan tersebut ingin terus mengembangkan usahanya, mengingat prospek usaha ke depan yang cerah karena permintaan keripik pisang terus meningkat. Penerapan teknologi tepat guna bertujuan untuk memperbaiki proses produksi yang selama ini masih menggunakan cara manual dan menciptakan diversifikasi rasa. Pengolahan keripik pisang dengan memanfaatkan teknologi tepat guna diharapkan akan dapat meningkatkan produksi dan pendapatan UKM mitra.

Widowati, 2004 mengatakan bahwa, teknologi tepat guna merupakan salah satu alternatif untuk mengatasi masalah yang dihadapi masyarakat. Teknologi tersebut berpotensi memenuhi beberapa kriteria antara lain : (a) mengkonversi sumberdaya alam, (b) menyerap tenaga kerja, (c) memacu industri rumah tangga, dan (d) meningkatkan pendapatan masyarakat. Selain itu, penerapan teknologi tepat guna di pedesaan dapat mempercepat pembangunan pedesaan secara ekonomi ( Anonimous, 2001).

\section{$\underline{\text { Target dan Luaran }}$}

Adapun Target dan Luaran yang diharapkan dari kegiatan PKM ini adalah :

1. Mitra mendapat pengetahuan bagaimana meningkatkan produksi keripik pisang sehingga dapat memenuhi permintaan pasar.

2. Mitra mendapat pengetahuan bagaimana menciptakan diversifikasi rasa keripik pisang.

3. Mitra mendapat pengetahuan bagaimana membuat disain dan kemasan keripik pisang yang menarik.

4. Mitra mendapat pengetahuan bagaimana melakukan menejemen usaha yang benar.

5. Mitra mendapat pengetahuan bagaimana menjalin kerja sama dengan minimarket dan toko oleh-oleh untuk memperluas jaringan pemasaran.

\section{METODE PELAKSANAAN}

Kegiatan pengabdian ini dimulai dengan kesepakatan kerja sama antara Tim Pengabdi dari FMIPA Unlam dengan khalayak sasaran (mitra) yaitu UKM keripik pisang Mawar dan UKM keripik pisang Kenanga. Tim pengabdi kemudian merumuskan masalah yang dihadapi oleh mitra. Kemudian masalah yang sudah dirumuskan kemudian dikaji oleh Tim Pengabdi dari FMIPA Unlam untuk dicari solusinya. Beberapa solusi yang dibuat Tim pengabdi FMIPA Unlam kemudian didiskusikan kembali dengan mitra untuk dicari solusi mana yang dapat dilaksanakan bersama.

Solusi yang disepakati antara Tim Pengabdi dengan mitra adalah, kegiatan ini diarahkan untuk menerapkan teknologi tepat guna untuk meningkatkan produksi, diversifikasi rasa keripik pisang, penyuluhan manajemen usaha, pendampingan pembuatan ijin usaha atau PIRT dan pendampingan kerja sama dengan minimarket dan toko oleh-oleh. Teknologi tepat guna yang akan digunakan adalah perajang pisang, spinner, alat pencampur bumbu, alat pengupas kulit pisang dan vacum sealer untuk mengemas keripik.

Pelaksanan kegiatan sosialisasi, pelatihan penggunaan teknologi tepat guna, dan penyuluhan manajemen usaha di lakukan dalam dua tahap. Hal ini dimaksudkan agar

proses alih ilmu pengetahuan dan teknologi dari tim pengusul PKM kepada UKM lebih

gampang dan mudah dipahami.

\section{Tahap Pertama}

1. Penjelasan secara teori alat perajang pisang, spinner, alat pencampur bumbu, alat pengupas pisang, dan vacum sealer yang meliputi: cara kerja, cara pemeliharaan dan hal-hal yang menyangkut keselamatan alat dan pelaksanaan di lapangan.

2. Peserta: Mitra I dan Mitra II .

3. Jenis kegiatan: pemaparan secara teori oleh tim pengusul PKM dan diskusi dengan

4. peserta.

5. Bahan: modul cara kerja dan cara pemeliharaan penggunaan peralatan

6. Penyuluhan tentang manajemen usaha.

7. Pendampingan pembuatan ijin usaha atau PIRT oleh pengabdi dibantu mahasiswa.

8. Pendampingan kerjasama dengan minimarket dan toko oleh-oleh, dibantu mahasiswa.

9. Pemberian pengetahuan tentang diversifikasi rasa

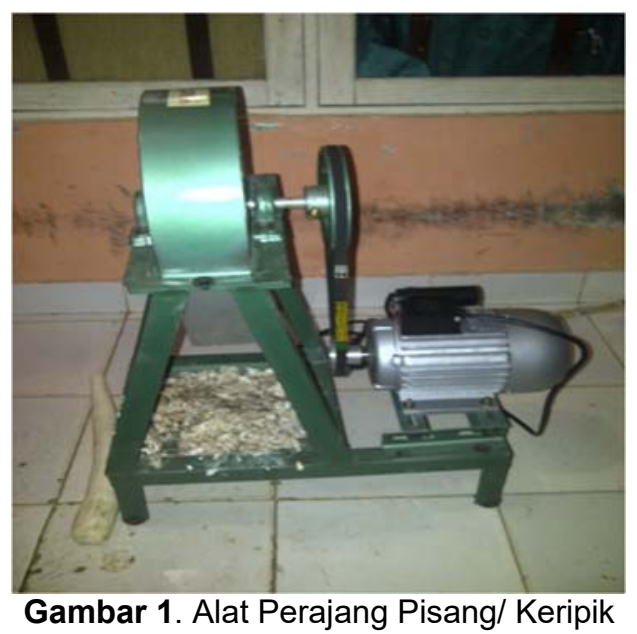




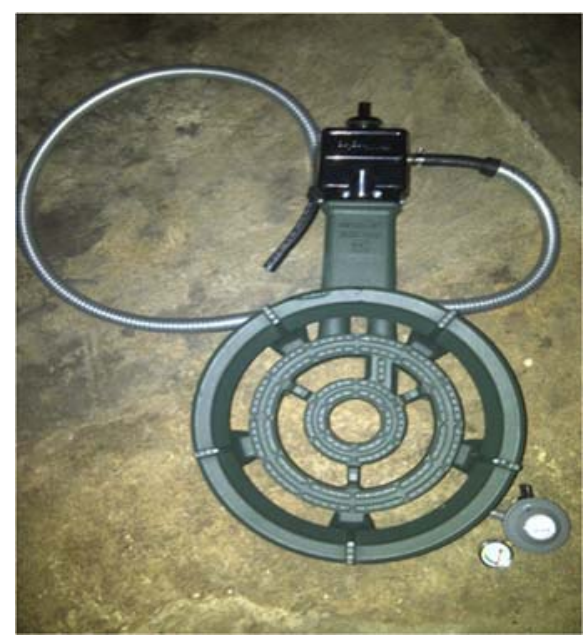

Gambar 2. Kompor Tungku Mata seribu

\section{Tahap Kedua}

Praktek langsung pengoperasian alat dengan bimbingan dan pendampingan oleh tim pengusul PKM. Setiap peserta langsung mencoba mengoperasikan alat tersebut dan bila ada kekurangan atau kekeliruan maka akan langsung dijelaskan oleh tim pengusul PKM.

Untuk mengatasi masalah manajemen usaha, akan dilakukan penyuluhan tentang bagaimana mengelola usaha sehingga dapat memberikan keuntungan. Untuk memudahkan pemahaman maka materi disusun dalam bentuk power point yang disertai gambar-gambar yang mudah dipahami dan didukung dengan penyampaian materi dalam bahasa setempat (bahasa banjar).

Pada kegiatan ini UKM berperan aktif khususnya pada kegiatan praktek pengoperasian alat. UKM juga perperan aktif di dalam menyediakan lahan dan tempat kegiatan. Setiap aktivitas pelatihan dan penyuluhan akan didampingi oleh Tim Pengabdi dan dibantu oleh 2 orang mahasiswa. Tugas mahasiswa adalah membantu proses pelatihan dan melakukan pendampingan selama proses pengabdian berjalan sampai mitra bisa mandiri, serta mendampingi pembuatan ijin usaha atau PIRT . Pada kegiatan ini mitra berperan aktif khususnya pada kegiatan praktek, penyediaan bahan dan tempat.

Dalam kegiatan ini mitra akan mendapatkan transfer iptek berupa alat perajang pisang, alat pengupas kulit pisang, spinner, alat pencampur bumbu dan vacum sealer untuk memperbaiki kemasan. Selain itu, akan dilakukan pelatihan dan pendampingan managemen usaha, serta pendaftaran produk keripik pisang ke BPOM untuk mendapatkan nomor PIRT dan pendampingan kerjasama dengan minimaket dan toko oleh-oleh untuk memperluas jaringan pemasaran

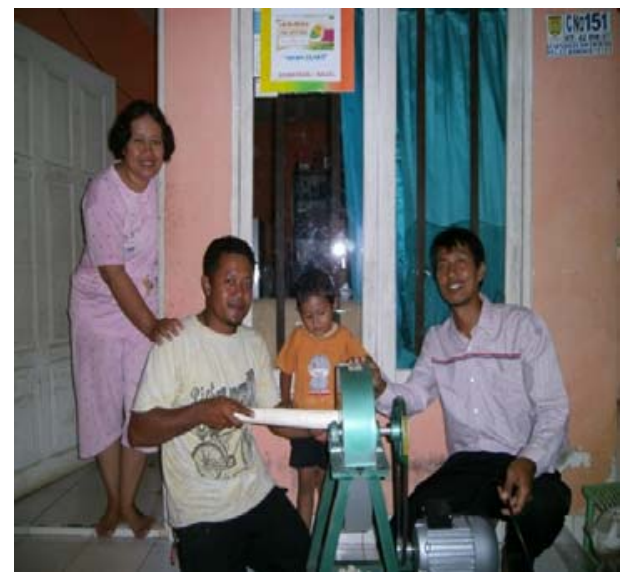

Gambar 3. Serah Terima Alat/ Teknologi

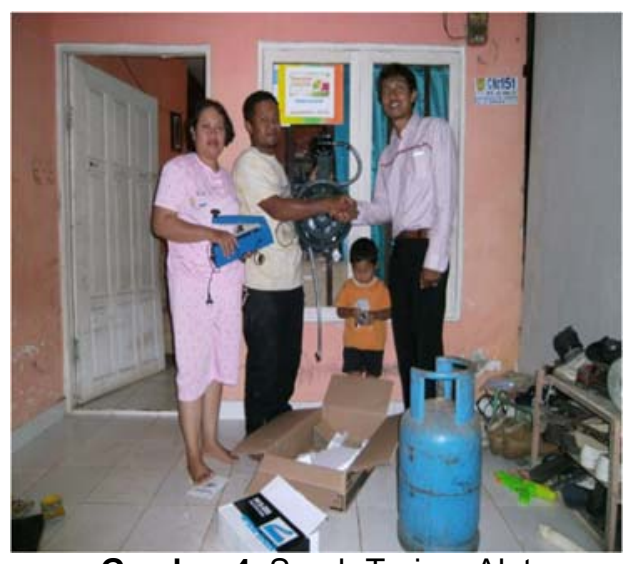

Gambar 4. Serah Terima Alat

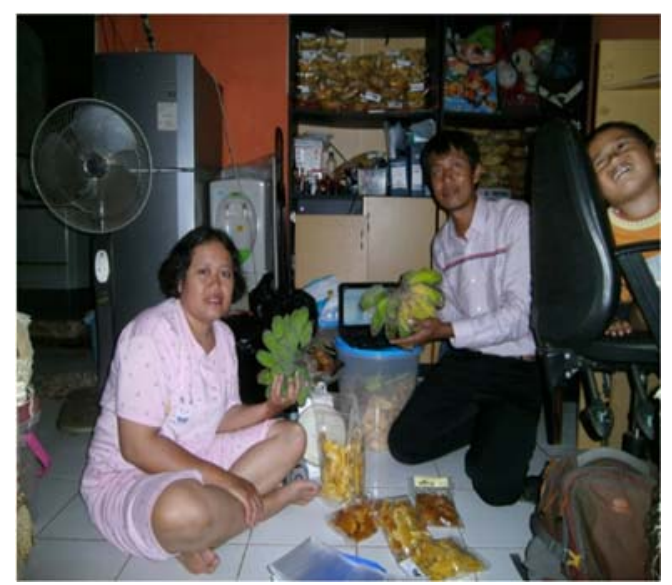

Gambar 5. Pelatihan 1 


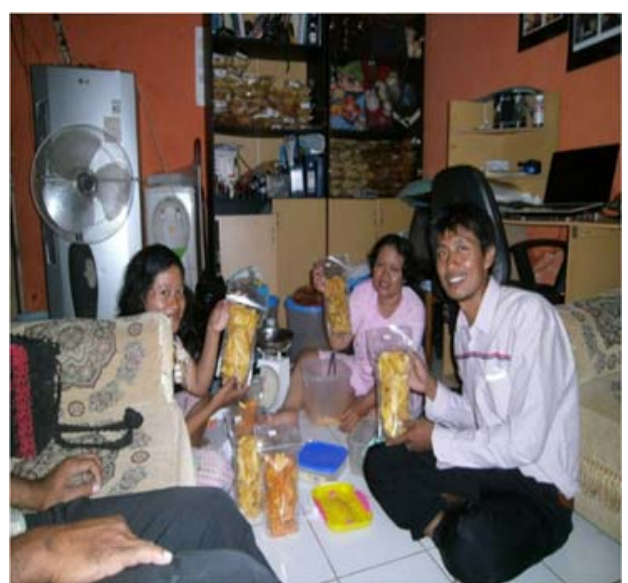

Gambar 6. Pelatihan II

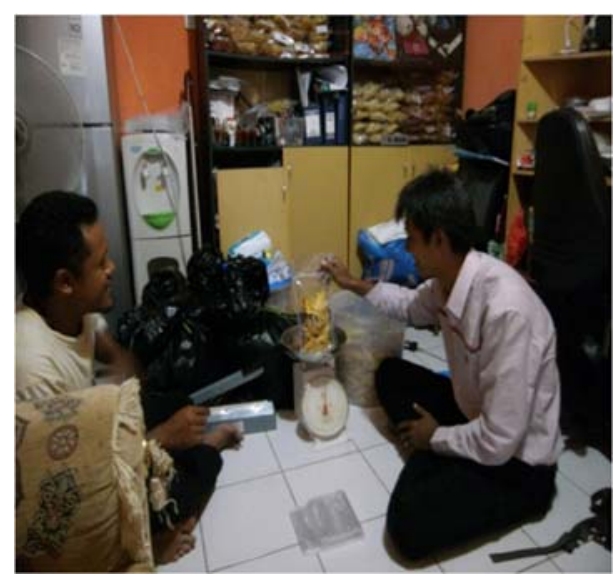

Gambar 7. Pelatihan III

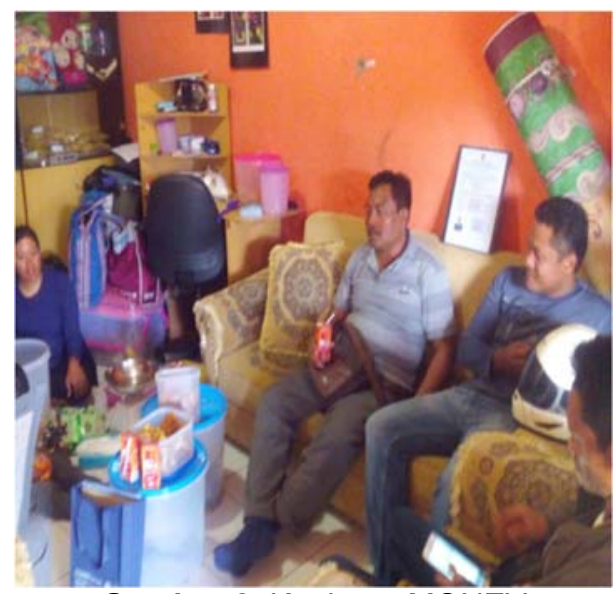

Gambar 8. Kegiatan MONEV

\section{Kelayakan Perguruan Tinggi}

Lembaga Pengabdian Masyarakat Unlam merupakan lembaga yang mengelola kegiatan pengabdian pada masyarakat yang dilakukan oleh para staf dosen Unlam, yang merupakan bentuk nyata dari Tri Darma perguruan tinggi. Pada satu tahun terakhir cukup banyak kegiatan pengabdian yang dilakukan dosen Unlam baik sumber dana mandiri ataupun dana hibah dari DIKTI. Beberapa dana hibah yang dikelola LPPM Unlam pada tahun 2017 adalah PKM sebanyak 14 judul, dan hibah KKN-PPM sebanyak 9 judul (LPPM Unlam, 2017). Kegiatan-kegiatan pengabdian tersebut sangat berarti bagi masyarakat Kalimantan Selatan, sehingga pemda setempat sangat mengharapkan adanya kegiatan pengabdian yang lebih banyak lagi yang dapat dilakukan oleh LPPM Unlam.

Tim pelaksana pengabdian pada masyarakat ini merupakan sinergi dari dosen Fakultas MIPA prodi Matematika yang mempunyai keahlian berbeda-beda. Ketua pelaksana memiliki pengetahuan dan pengalaman tentang penggunanan teknologi tepat guna yang di aplikasikan pada perusahaan keripik pisang, dan telah mendapatkan pelatihan dari dinas koperasi dan UMKM kabupaten Banjar tentang jenis dan pemanfaatan teknologi tepat guna untuk mengembangkan UMKM pada tahun 2016. Anggota kegiatan PKM, memiliki pengetahuan tentang manajemen usaha, anggota kegiatan juga merupakan praktisi di bidang penjualan Online selama kurang lebih 5 tahun, sehingga memiliki kemampuan managemen usaha yang mumpuni, yang dapat ditularkan ke UKM keripik pisang. Dengan sinergi yang baik dari tim pengusul maka kegiatan ini akan berjalan dengan lancar dan akan tercapainya target luaran yang diharapkan.

Untuk mendukung kelancaran dan keberhasilan pengabdian, kegiatan pengabdian ini didukung oleh sarana dan prasarana di Fakultas MIPA Unlam, sebagai berikut :

1. Bengkel kerja di Prodi Fisika.

2. Laboratorium Mikrobiologi pangan di Prodi Biologi

3. Laboratorium Komputasi Matematika

\section{HASIL DAN PEMBAHASAN}

Hasil dan Luaran yang dihasilkan dari program PKM ini khususnya untuk pihak mitra adalah:

1. Terdapat peralatan teknologi tepat guna untuk produksi keripik pisang.

2. Terdapat peningkatan produksi keripik pisang hingga $50 \%$.

3. Terdapat diversifikasi rasa keripik, yaitu rasa barbeque, sapi panggang, balado dan keju.

4. Meningkatkan pendapatan UKM keripik pisang hingga $45 \%$ dari pendapatan sebelum adanya kegiatan PKM.

5. Terdapat kemasan yang menarik dan ijin usaha atau PIRT.

6. Terdapat jalinan kerjasama dengan minimarket dan toko oleh-oleh. 


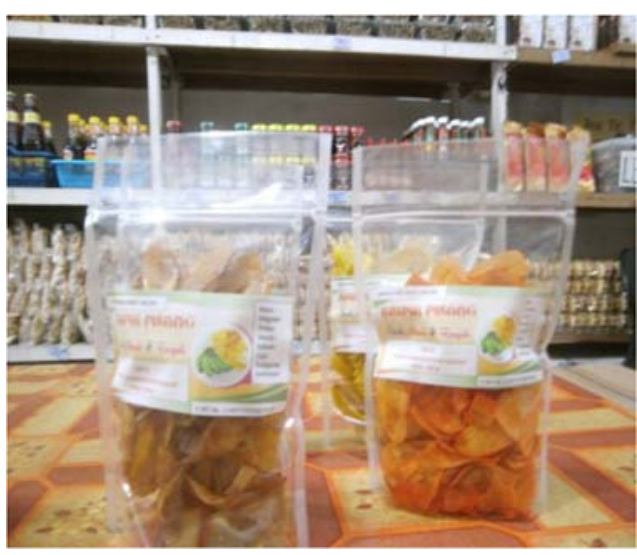

Gambar 9. Produk PKM

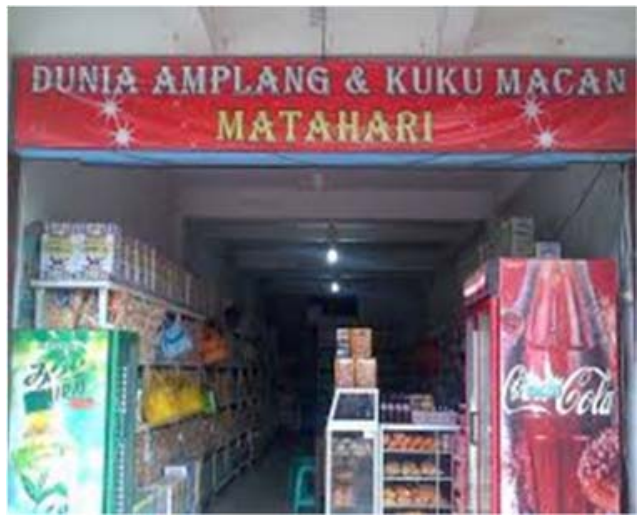

Gambar 10. Toko Oleh oleh I

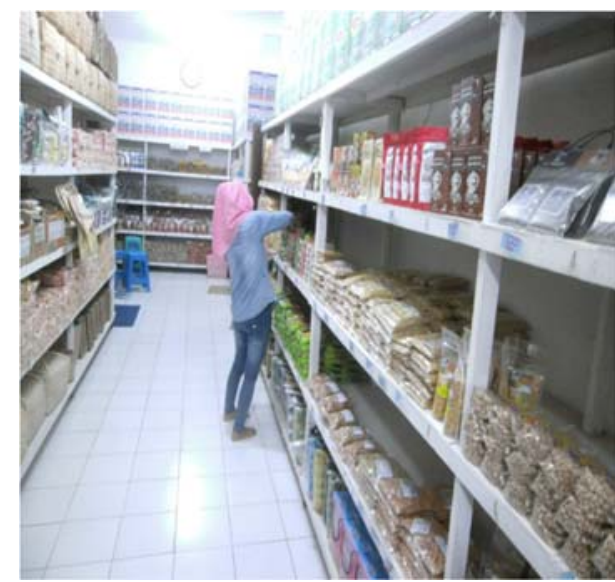

Gambar 11. Toko Oleh-oleh II

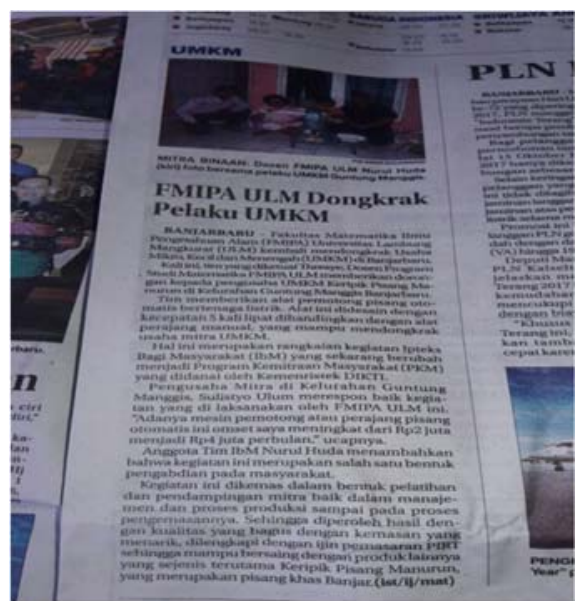

Gambar 12. Publikasi Koran

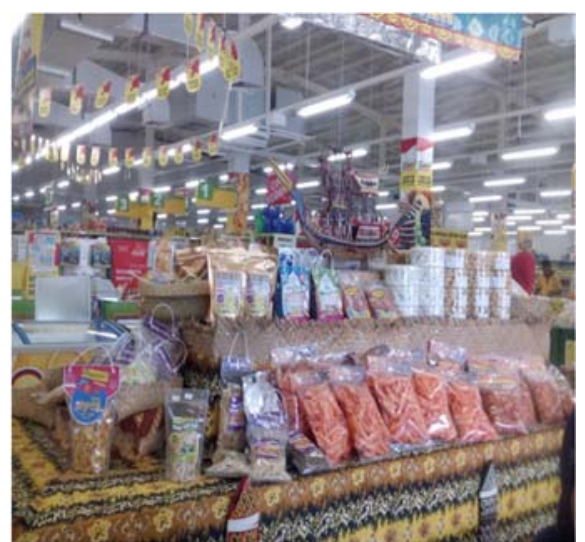

Gambar 13. Toko Oleh-oleh III

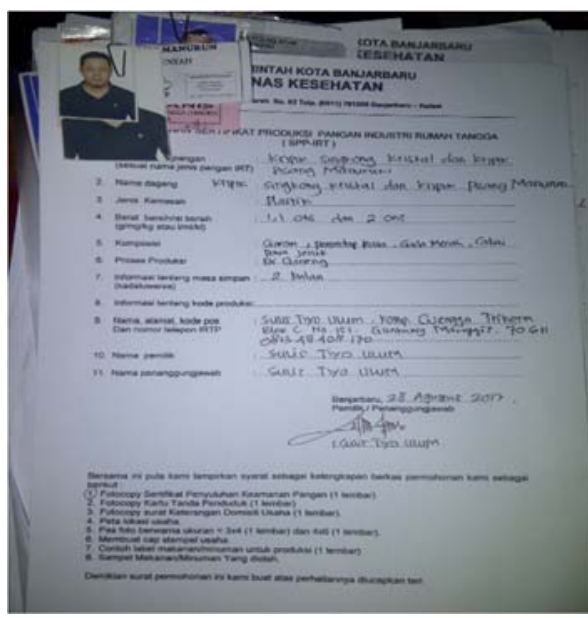

Gambar 14. ljin PIRT I 


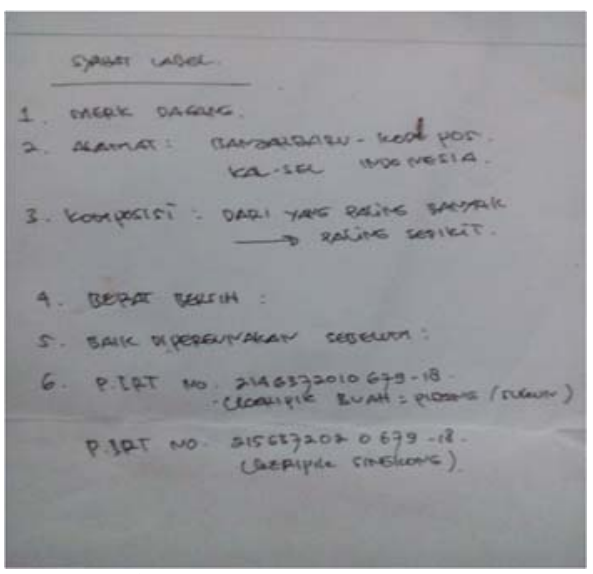

Gambar 15. Ijin PIRT II

\section{SIMPULAN DAN SARAN}

\section{Simpulan}

Kesimpulan yang diperoleh dari kegiatan PKM ini adalah:

1. Terdapat peralatan teknologi tepat guna untuk produksi keripik pisang.

2. Terdapat peningkatan produksi keripik pisang hingga $50 \%$, dari 4 Tandon Pisang Per Minggu menjadi 6 Tandon Pisang Per Minggu.

3. Terdapat diversifikasi rasa keripik, yaitu rasa barbeque, sapi panggang, balado dan keju, sebelumnya hanya rasa original dan Pedas

4. Meningkatkan pendapatan UKM keripik pisang hingga $45 \%$ dari pendapatan sebelum adanya kegiatan PKM, dari 1,5 juta menjadi 2 Juta.

5. Terdapat kemasan yang menarik dan ijin usaha atau PIRT

6. Terdapat Publikasi di media massa sehingga dikenal masyarakat

7. Terdapat jalinan kerjasama dengan minimarket dan toko oleh-oleh

\section{Saran}

Adapun Saran dari Kegiatan ini adalah:

1. Mitra dapat meningkatkan pendapatan dan meningkat taraf kesejahteraan hidupnya.

2. Produk Mitra semakin dikenal masyarakat.

\section{UCAPAN TERIMA KASIH}

Terima kasih kami sampaikan kepada segala pihak yang telah berkontribusi dalam perencanaan, pelaksanaan, dan pembuatan laporan Akhir pelaksanaan kegiatan. Dalam hal ini kami berterima kasih kepada:

Menteri Ristek dan Teknologi atas Hibah yang diberikan

1. Bapak Rektor Universitas Lambung Mangkurat

2. Bapak Ketua LPPM Unlam

3. Bapak Dekan FMIPA Unlam

4. Bapak Lurah Guntung Manggis

5. Bapak Lurah Pesayangan
6. Mitra I di Banjarbaru

7. Mitra II di Martapura

8. Para Mahasiswa yang telah mengikuti kegiatan PKM

9. Kepada Seluruh Pihak yang telah membantu kegiatan ini.

\section{DAFTAR RUJUKAN}

Anonim, 2000. Teknologi Tepat Guna. Ditjen Pemberdayaan Masyarakat Desa kerjasama dengan Sekolah Tinggi Pemerintahan Dalam Negeri. Jakarta.

Dinas Perkebunan, Pertanian dan Perkebunan Kabupaten Banjar. 2014. Data produksi Umbi-Umbian dan Buah-buahan. 2011.

Dinas Perindustrian dan perdagangan kabupaten Banjar 2015. Data industri kecil/kerajinan di Kabupaten banjar tahun 2014.

Dinas pertanian tanaman pangan dan Hortilultura Kabupaten Banjar. 2015. Data Jumlah produksi tanaman Pangan tahun 2014.

LPPM. 2016. Rekap Kegiatan Lembaga Pengabdian Masyarakat Universitas Lambung Mangkurat Banjarmasin.

Widowati, S, N. Richana, Suarni, P. Raharto, IGP. Sarasutha. 2001. Studi Potensi dan Peningkatan Dayaguna Sumber Pangan Lokal Untuk Penganekaragaman Pangan di Sulawesi Selatan. Lap. Hasil Penelitian. Puslitbangtan, Bogor. 